\section{Gold as a Novel Catalyst in the 21st Century: Preparation, Working Mechanism and Applications}

\author{
Masatake Haruta \\ Research Institute for Green Technology, AIST \\ 16-1 Onogawa, Tsukuba 305-8569, Japan \\ Email:m.haruta@aist.go.jp
}

Gold can be deposited as nanoparticles on a variety of support materials by coprecipitation or depositionprecipitation of $\mathrm{Au}(\mathrm{OH})_{3}$, grafting of organo-gold complexes such as dimethyl-Au(III)-acetylacetonate, mixing of colloidal Au particles, and vacuum deposition. Owing to the moderate adsorption of at least one of reactants (for example, $\mathrm{CO}$ ) on the edges and corners of $\mathrm{Au}$ nanoparticles and to the activation of the counter reactant (for example, $\mathrm{O}_{2}$ ) at the perimeter interface with the supports, supported $\mathrm{Au}$ nanoparticle catalysts exhibit unique and practically useful catalytic properties at relatively low temperature below 473K. They have already been commercially used for deodorizers in rest rooms in Japan and will find growing applications in indoor air quality control, pollutant emission control, production of hydrogen energy carrier, and innovations in chemical processes. Cluster science of Au may also open an exciting area of research showing some magic numbers for dramatic changes in reactivity.

\section{Introduction}

Historically, gold was regarded to be catalytically inert, but since the discovery of surprisingly high catalytic activity for low-temperature CO oxidation (1), it has been shown that gold becomes active for many reactions when stabilized in the form of nanoparticles attached to metal oxide and activated carbon supports (2-5). In the 1990's, R\&D activity on the catalysis of Au tended to grow appreciably (3). This paper focuses on recent advances, especially in the techniques for preparing highly dispersed Au catalysts, a working mechanism for CO oxidation, and potential applications and future prospects.

\section{Preparation of nanoparticulate $\mathrm{Au}$ catalysts}

It is difficult to deposit Au as nanoparticles on metal oxide supports by impregnation methods mainly because Au has a lower melting point and a lower affinity for metal oxides than $\mathrm{Pd}$ and Pt. Another reason is that during calcination of $\mathrm{HAuCl}_{4}$ crystallites which are dispersed on the support surfaces, chloride ion markedly enhances the coagulation of gold particles. As summarized in Table 1, there are four categories of techniques that can lead to the deposition of $\mathrm{Au}$ nanoparticles with diameters below $10 \mathrm{~nm}$ (6). It is very important to choose a suitable technique depending on the kind of support materials such as basic or acidic metal oxides, carbonaceous materials, or single crystals.

The first category is characterized by the preparation of well-mixed precursors, for example, hydroxide, oxide, or metal mixtures of $\mathrm{Au}$ with the metal component of the support by coprecipitation (7), amorphous alloying (11) or co-sputtering (12), respectively. These precursor mixtures are then transformed during calcination in air at temperatures above 550K into metallic Au particles strongly attached to the crystalline metal oxides such as $\alpha-\mathrm{Fe}_{2} \mathrm{O}_{3}, \mathrm{CO}_{3} \mathrm{O}_{4}$, and $\mathrm{NiO}$.

Among the three techniques, coprecipitation is the most useful and simplest method of preparation. An aqueous solution of $\mathrm{HAuCl}_{4} \bullet 4 \mathrm{H}_{2} \mathrm{O}$ and water soluble metal salts, most preferably nitrates, such as $\mathrm{Fe}\left(\mathrm{NO}_{3}\right)_{2} \bullet 9 \mathrm{H}_{2} \mathrm{O}$ is poured into an aqueous alkaline solution under agitation for a few minutes. After ageing for 1 hour, the precipitates are washed with water for more than 5 times and filtered. The hydroxide and/or carbonate mixture is dried overnight and calcined to obtain powder catalysts. What are important to obtain homogeneous dispersion of Au nanoparticles can be summarized as follows.

1) Concentrating of metal salts solution: $0.1-0.4 \mathrm{M} / \mathrm{l}$.

2) Neutralizer: $\mathrm{Na}_{2} \mathrm{CO}_{3}$ or $\mathrm{K}_{2} \mathrm{CO}_{3}$

Since gold hydroxide, $\mathrm{Au}(\mathrm{OH})_{3}$, is amphoteric, its solubility 
Table 1

Preparation Techniques for Nanoparticulate Gold Catalysts

\begin{tabular}{|c|c|c|c|}
\hline Categories & Preparation techniques & Support materials & Ref. \\
\hline \multirow{3}{*}{$\begin{array}{l}\text { Preparation of mixed } \\
\text { precursors of } \mathrm{Au} \\
\text { and the metal } \\
\text { component of } \\
\text { supports }\end{array}$} & coprecipitation (hydroxides or carbonates) CP & $\begin{array}{c}\mathrm{Be}(\mathrm{OH})_{2}, \mathrm{TiO}_{2}^{*}, \mathrm{Mn}_{2} \mathrm{O}_{3}, \mathrm{Fe}_{2} \mathrm{O}_{3}, \mathrm{CO}_{3} \mathrm{O}_{4} \\
\mathrm{NiO}, \mathrm{ZnO}, \mathrm{In}_{2} \mathrm{O}_{3}, \mathrm{SnO}_{2}\end{array}$ & $1,7,8,9,10$ \\
\hline & amorphous alloy (metals) AA & $\mathrm{ZrO}_{2}$ & 11 \\
\hline & co-sputtering (oxides) in the presence of $\mathrm{O}_{2} \mathrm{CS}$ & $\mathrm{CO}_{3} \mathrm{O}_{4}$ & 12 \\
\hline \multirow{3}{*}{$\begin{array}{l}\text { Strong interaction } \\
\text { of Au precursors with } \\
\text { support materials }\end{array}$} & $\begin{array}{c}\text { deposition-precipitation }\left(\mathrm{HAuCl}_{4} \text { in aqueous }\right. \\
\text { solution) DP }\end{array}$ & $\begin{array}{c}\mathrm{Mg}(\mathrm{OH})_{2}{ }^{*}, \mathrm{Al}_{2} \mathrm{O}_{3}, \mathrm{TiO}_{2}, \mathrm{Fe}_{2} \mathrm{O}_{3}, \mathrm{CO}_{3} \mathrm{O}_{4}, \mathrm{NiO} \\
\mathrm{ZnO}, \mathrm{ZrO}_{2}, \mathrm{CeO}_{2}, \mathrm{Ti}_{-} \mathrm{SiO}_{2}\end{array}$ & 13,14 \\
\hline & $\begin{array}{c}\text { liquid phase grafting (organogold complex in } \\
\text { organic solvents) LG }\end{array}$ & $\mathrm{TiO}_{2}, \mathrm{MnOx}, \mathrm{Fe}_{2} \mathrm{O}_{3}$ & 15,16 \\
\hline & gas phase grafting (organogold complex) GG & $\begin{array}{l}\text { all kinds, including } \mathrm{SiO}_{2}, \mathrm{Al}_{2} \mathrm{O}_{3}-\mathrm{SiO}_{2} \\
\text { and activated carbon }\end{array}$ & 17,18 \\
\hline $\begin{array}{l}\text { Mixing colloidal Au } \\
\text { with support materials }\end{array}$ & colloid mixing $\mathrm{CM}$ & $\mathrm{TiO}_{2}$, activated carbon & 19,20 \\
\hline $\begin{array}{l}\text { Model catalysts using } \\
\text { single crystal supports }\end{array}$ & $\begin{array}{l}\text { vacuum deposition VD } \\
\text { (at low temperature) }\end{array}$ & $\begin{array}{l}\text { Defects are the sites for deposition, } \\
\qquad \mathrm{MgO}, \mathrm{SiO}_{2}, \mathrm{TiO}_{2}\end{array}$ & $21,22,23$ \\
\hline
\end{tabular}

* The addition of Mg citrate during or after coprecipitation or deposition-precipitation is important for depositing Au as nanoparticles.

increases due to the formation of $\mathrm{Au}(\mathrm{OH})_{4}$ - anion when the $\mathrm{pH}$ is too high. Therefore, precipitation is most efficient in the $\mathrm{pH}$ range of 7-10. When metal salt solution is added to $\mathrm{Na}_{2} \mathrm{CO}_{3}$ or $\mathrm{K}_{2} \mathrm{CO}_{3}$ solution, precipitate can be formed at a relatively constant $\mathrm{pH}$. When $\mathrm{NaOH}$ solution is used, its $\mathrm{pH}$ inevitably changes during coprecipitation. The use of $\mathrm{NH}_{4} \mathrm{OH}$ solution usually results in the formation of $\mathrm{Au}$ particles larger than $10 \mathrm{~nm}$ in diameter. However, it has recently been reported that ageing for several hours leads to small Au nanoparticles when homogeneous precipitation using urea as a neutralizer is applied (24).

3) Temperature: $320-360 \mathrm{~K}$ for precipitation and 550-670K for calcination

Aqueous solutions for coprecipitation should be warmed to a temperature in the range of $320-360 \mathrm{~K}$ to promote the exchange of chloride from the $\mathrm{AuCl}_{4}{ }^{-}$ion with $\mathrm{OH}$. In the case of $\mathrm{Au} / \mathrm{CO}_{3} \mathrm{O}_{4}$, coprecipitation should be carried out in the temperature range of $270-300 \mathrm{~K}$ for the sake of depressing the reduction of $\mathrm{AuCl}_{4}{ }^{-}$ion with the oxidation of $\mathrm{Co}^{2+}$ ion to $\mathrm{Co}^{3+}$ ion. The catalytic activity for lowtemperature CO oxidation of coprecipitates reaches a maximum when they are calcined in air at temperatures above 550K, where Au hydroxide species mostly change to metallic Au particles (8). Above 670K, the sintering of Au nanoparticles becomes accelerated.

Figure 1 shows a TEM photograph for $\mathrm{Au} / \alpha-\mathrm{Fe}_{2} \mathrm{O}_{3}$ prepared by coprecipitation. Gold nanoparticles are homogeneously dispersed on $\alpha-\mathrm{Fe}_{2} \mathrm{O}_{3}$ particles, with a standard deviation of the diameter of about $30 \%$. The applicability of coprecipitation is limited to metal hydroxides or carbonates that can be coprecipitated with $\mathrm{Au}(\mathrm{OH})_{3}$.
Actually, Au can be supported in the form of well-dispersed nanoparticles on $\alpha-\mathrm{Fe}_{2} \mathrm{O}_{3}, \mathrm{CO}_{3} \mathrm{O}_{4}, \mathrm{NiO}$, and $\mathrm{ZnO}$ while not on $\mathrm{TiO}_{2}, \mathrm{Cr}_{2} \mathrm{O}_{3}, \mathrm{MnOx}$, and $\mathrm{CdO}$ (7). In the case of $\mathrm{TiO}_{2}$, the addition of $\mathrm{Mg}$ citrate during or after coprecipitation results in a good dispersion (9), while in the case of $\mathrm{Mn}_{2} \mathrm{O}_{3}$, precipitation with $\mathrm{LiCO}_{3}$ solution leads to better catalytic activity for CO oxidation in a hydrogen stream (10).

The second category is based on the deposition or adsorption of Au compounds, for example, Au hydroxide by deposition-precipitation (DP) (13) or an organogold complex by liquid phase grafting (LG) $(15,16)$ and by gas phase

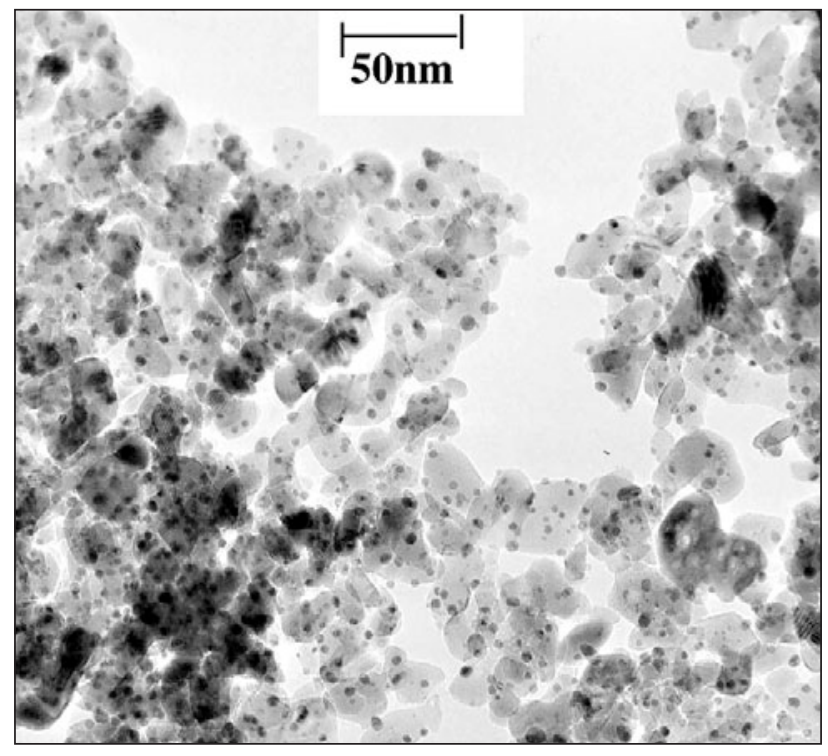

Figure 1

TEM photograph for $\mathrm{Au} / \alpha-\mathrm{Fe}_{2} \mathrm{O}_{3}$ prepared by coprecipitation followed by calcination at $673 \mathrm{~K}$ 


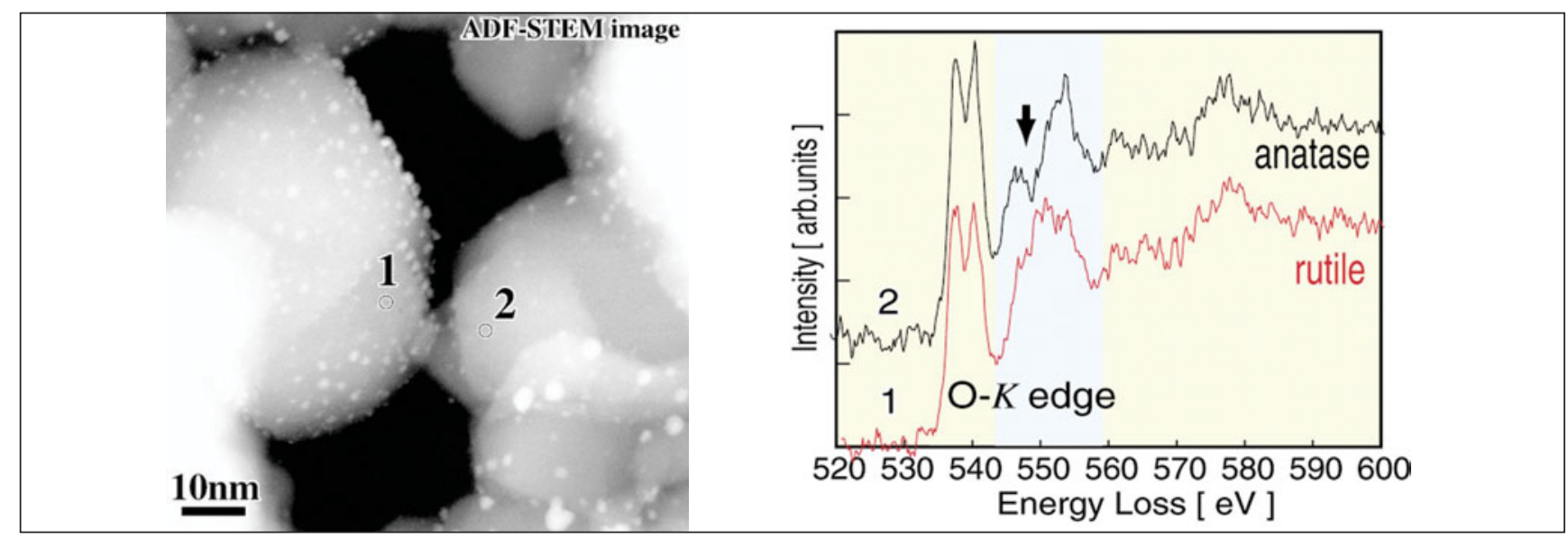

\section{Figure 2}

ADF-STEM and EELS analyses for Au/TiOz $(p-25)$ prepared by deposition-precipitation

grafting (GG) (17). The DP method is the easiest to handle and is used for producing commercial Au catalysts. Due to the amphoteric properties of $\mathrm{Au}(\mathrm{OH})_{3}$, the $\mathrm{pH}$ of aqueous $\mathrm{HAuCl}_{4}$ solution is adjusted at a fixed point in the range of 6 to 10 , and is selected primarily based on the isoelectric points (IEP) of the metal oxide supports. Careful control of the concentration around $10^{-3} \mathrm{M} / \mathrm{l}$, with the $\mathrm{pH}$ in the range of 6 to 10 , and the temperature in the range of $323 \mathrm{~K}$ to $363 \mathrm{~K}$ of the aqueous $\mathrm{HAuCl}_{4}$ solution enables selective deposition of $\mathrm{Au}(\mathrm{OH})_{3}$ only on the surfaces of the support metal oxides without precipitation in the liquid phase. Because the precursor can be washed before drying, $\mathrm{Na}$ and $\mathrm{Cl}$ ions are removed to a level of a few tens ppm. As in the case of coprecipitation, the removal of $\mathrm{Cl}^{-}$ions by washing can avoid the coagulation of Au nanoparticles.

The only constraint of DP is that it is not applicable to metal oxides, the IEPs of which are below 5, and to activated carbon. Gold hydroxide cannot be deposited on $\mathrm{SiO}_{2}(\mathrm{IEP}=2)$, $\mathrm{SiO}_{2}-\mathrm{Al}_{2} \mathrm{O}_{3} \quad(\mathrm{IEP}=1)$, or $\mathrm{WO}_{3}(\mathrm{IEP}=1)$. Liquid phase grafting in organic solvent has also the same constraint and furthermore it needs freshly prepared metal hydroxides (15), probably because the concentration of surface $\mathrm{OH}$ groups should be high enough for the interaction with organo-gold complexes. In contrast, by using dimethyl-Au(III)-aceytylacetonate (25), $\mathrm{GG}$ is unique because it can deposit $\mathrm{Au}$ nanoparticles on almost all kinds of supports, for example, $\mathrm{SiO}_{2}$ and $\mathrm{SiO}_{2}-\mathrm{Al}_{2} \mathrm{O}_{3}$, and activated carbon (18).

The third category is to use monodispersed Au colloids stabilized by organic ligands or polymer compounds $(19,20)$. Among the former six techniques, only GG is effective for depositing Au nanoparticles on activated carbon, but the sizes of Au particles are relatively large (around $10 \mathrm{~nm}$ ). Precise control of dispersion and size (within $5 \mathrm{~nm}$ in diameter) of Au nanoparticles can be accomplished by dipping Au sols stabilized with polyvinyl pyrrolidone or tetrakis(hydroxymethyl)phosphonium chloride (20).

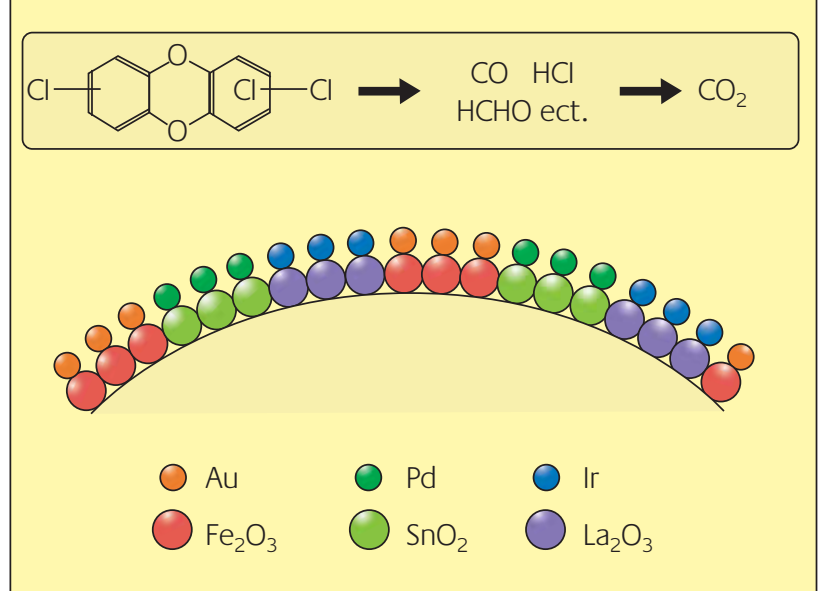

Figure 3

Schematic representation of a multi-functional catalyst integrating three supported precious metal catalysts, $\mathrm{Pd} / \mathrm{SnO} \mathrm{O}_{2}, \mathrm{Ir} / \mathrm{La}_{2} \mathrm{O}_{3}$ and $\mathrm{Au} / \propto-\mathrm{Fe}_{2} \mathrm{O}_{3}$

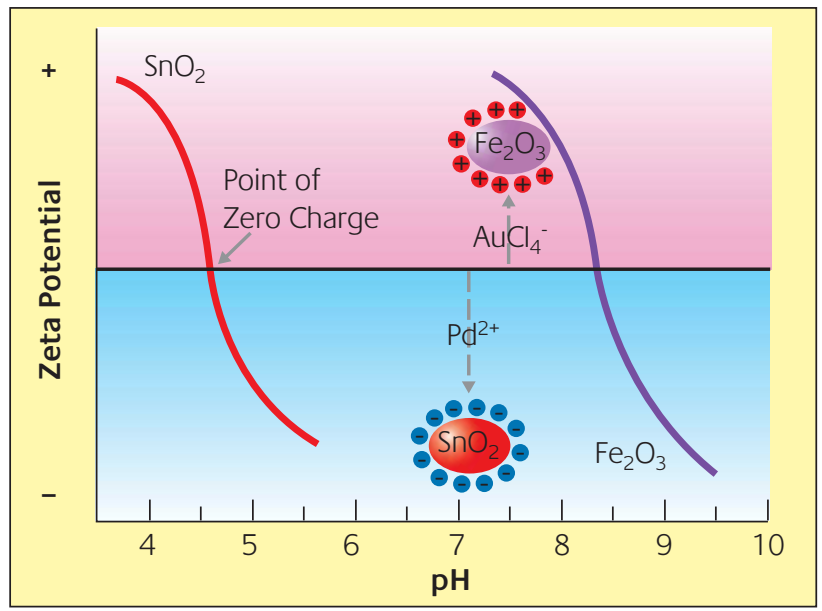

Figure 4

Schematic drawing for the selective deposition of $\mathrm{Pd}$ on $\mathrm{SnO}_{2}$ and of $\mathrm{Au}$ on $\alpha-\mathrm{Fe}_{2} \mathrm{O}_{3}$ 
In the preparation of model catalysts, on single crystals of $\mathrm{MgO}$ and $\mathrm{TiO}_{2}$ (rutile), size selected Au anion clusters can be deposited with homogeneous dispersion at relatively low temperatures $(21,23)$. Surface defects or specific surface cages are suggested as sites for stabilizing the Au clusters $(21,22)$.

By utilizing the $\mathrm{pH}$ dependency of Au deposition in DP, Au nanoparticles can be deposited on a specific site of support materials or on a specific kind and crystallite of metal oxide mixtures. When $\mathrm{TiO}_{2}$ powder (Degussa P25) which had been considered to be composed of anatase and rutile was used as a support, as shown in Figure 2, Au particles were deposited densely on one group of $\mathrm{TiO}_{2}$ particles whereas they were rarely deposited on another group of $\mathrm{TiO}_{2}$ particles (26). TEM observation and EELS spectra proved that Au particles were deposited on rutile but not on anatase, revealing that $\mathrm{P} 25 \mathrm{TiO}_{2}$ was composed of two types of crystalline particles, not of a homogeneous or surfacecovered mixture in one single particle.

In the case of $\mathrm{TiO}_{2}$ deposited on $\mathrm{SiO}_{2}$ and titanosilicates where titanium cations are incorporated as isolated species in the matrix of $\mathrm{SiO}_{2}$, DP leads to the selective deposition of $\mathrm{Au}$ nanoparticles on $\mathrm{TiO}_{2}$ or isolated $\mathrm{Ti}$ cation sites, not on $\mathrm{SiO}_{2}$ surfaces. This structure is indispensable for the selective epoxidation of propylene using gas streams containing $\mathrm{O}_{2}$ and $\mathrm{H}_{2}$ (27). The same catalytic system prepared by GG which enables the non-selective deposition of Au particles both on $\mathrm{TiO}_{2}$ and $\mathrm{SiO}_{2}$, is not selective at all for the epoxidation of propylene.

In future applications gold catalysts may be used in combination with other precious metal catalysts and base metal oxide catalysts, especially in environmental pollutant abatement. We have demonstrated that the most effective approach is to integrate a few different supported nanoscale precious metal catalysts, as schematically shown in Figure 3. The idea is to combine synergistically the different performances of each precious metal by choosing the most suitable support for a target reaction and then by integrating them into a single catalytic system. An integrated catalyst composed of $\mathrm{Pd} / \mathrm{SnO}_{2}$, Ir/ $/ \mathrm{La}_{2} \mathrm{O}_{3}$, and $\mathrm{Au} / \mathrm{Fe}_{2} \mathrm{O}_{3}$ exhibited enhanced catalytic activities not only for dioxin decomposition but also for the oxidation of $\mathrm{H}_{2}$ and $\left(\mathrm{CH}_{3}\right)_{3} \mathrm{~N}(28)$.

A mixture of $\mathrm{SnO}_{2}$ and $\mathrm{Fe}_{2} \mathrm{O}_{3}$ was prepared by coprecipitation from an aqueous solution of $\mathrm{SnCl}_{4}$ and $\mathrm{Fe}\left(\mathrm{NO}_{3}\right)_{2}$, followed by calcination in air at 673K. Figure 4 shows a guiding principle for the selective deposition of Pd and Au. Palladium was first deposited by DP from an aqueous solution of $\mathrm{Pd}\left(\mathrm{CH}_{3} \mathrm{COO}\right)_{2}$ at $\mathrm{pH}=7$, where the $\mathrm{Pd}^{2+}$ cation could approach negatively charged $\mathrm{SnO}_{2}$, but was not allowed to approach $\mathrm{Fe}_{2} \mathrm{O}_{3}$ which is positively charged. After washing and calcination at $673 \mathrm{~K}$, the sample composed of $\mathrm{PdO} / \mathrm{SnO}_{2}$ and $\mathrm{Fe}_{2} \mathrm{O}_{3}$ was aged in an aqueous solution of $\mathrm{HAuCl}_{4}$ at
$\mathrm{pH} 7.5$. Gold hydroxide $\mathrm{Au}(\mathrm{OH})_{3}$ was then selectively deposited from $\mathrm{Au}(\mathrm{OH})_{n} \mathrm{Cl}_{4^{-}{ }_{n}}$ anion on the positively charged $\mathrm{Fe}_{2} \mathrm{O}_{3}$, without precipitation on the negatively charged $\mathrm{SnO}_{2}$. After washing and calcination, the sample composed of $\mathrm{PdO} / \mathrm{SnO}_{2}$ and $\mathrm{Au} / \mathrm{Fe}_{2} \mathrm{O}_{3}$ was dispersed in an aqueous solution of $\mathrm{Na}_{2} \mathrm{CO}_{3}$, to which an aqueous solution of $\mathrm{IrCl}_{4}$ and $\mathrm{La}\left(\mathrm{NO}_{3}\right)$ was poured to obtain finally a mixture of $\mathrm{Pd} / \mathrm{SnO}_{2}+\mathrm{Ir} / \mathrm{La}_{2} \mathrm{O}_{3}+\mathrm{Au} / \mathrm{Fe}_{2} \mathrm{O}_{3}$ through washing, calcination, and reduction in $\mathrm{H}_{2}$ stream.

\section{Structure Sensitivity of CO Oxidation}

Except for $\mathrm{H}_{2}$ oxidation and hydrocarbon hydrogenations, most reactions are remarkably structure-sensitive over supported Au catalysts. The oxidation of $\mathrm{CO}$ is the simplest reaction and has been the most intensively studied (29). This reaction is practically important in the purification of engine exhaust gases and of hydrogen produced by steam reforming of methanol and hydrocarbons for polymer electrolyte fuel cells (10). The oxidation of CO over Au catalysts is remarkably sensitive to the contact structure between the Au particles and the support, the type of support, and the size the $\mathrm{Au}$ particles.

\section{1) Contact Structure of Gold Particles}

Table 2 lists the turnover frequencies (TOFs), the reaction rates over one single surface metal atom per second, of CO oxidation at $300 \mathrm{~K}$ over $\mathrm{Pt} / \mathrm{TiO}$ and $\mathrm{Au} / \mathrm{TiO}_{2}$ catalysts prepared by DP, photochemical deposition, and IMP methods (30). The DP method yields hemispherical metal particles with their flat planes strongly attached to the $\mathrm{TiO}_{2}$ support, often by epitaxial contact, $\mathrm{Au}(111)$ to anatase $\mathrm{TiO}_{2}$ (112) and rutile $\mathrm{TiO}_{2}$ (110), while photocatalytic deposition and IMP methods yield spherical particles, which are simply loaded on the $\mathrm{TiO}_{2}$ support and, therefore, are much larger, particularly in the case of $\mathrm{Au}$. Over $\mathrm{Pt} / \mathrm{TiO}_{2}$, the reaction of $\mathrm{CO}$ with $\mathrm{O}_{2}$ takes place preferentially on the Pt surfaces and the metal oxide support is less involved in the reaction. This can explain why different methods of preparation do not make any appreciable difference in the TOF of Pt catalysts. In contrast, the TOF of $\mathrm{Au} / \mathrm{TiO}_{2}$ markedly depends on the methods of preparation and varies by four orders of magnitude. The TOF of strongly attached hemispherical Au particles exceeds that of Pt by one order of magnitude. The dramatic difference in TOFs suggests that the contact structure is the most critical factor in supported Au catalysts.

The sharp contrast between the above two precious metal catalysts in $\mathrm{CO}$ oxidation suggests that the reactions might take place at the perimeter interfaces around the $\mathrm{Au}$ particles. To confirm this hypothesis, Vannice prepared an inversely supported catalyst, namely, $\mathrm{TiO}_{2}$ layers deposited on 
Table 2

$\mathrm{CO}$ oxidation over $\mathrm{Pt} / \mathrm{TiO}_{2}$ and $\mathrm{Au} / \mathrm{TiO} 2$ prepared by different methods (30)

\begin{tabular}{|c|c|c|c|c|c|c|c|}
\hline Metal & $\begin{array}{l}\text { Preparation } \\
\text { methods }\end{array}$ & $\begin{array}{l}\text { Metal loading } \\
\text { (wt\%) }\end{array}$ & $\begin{array}{l}\text { Diameter of } \\
\text { Au }(n m)\end{array}$ & $\begin{array}{l}T_{1 / 2}{ }^{*} \\
(K)\end{array}$ & $\begin{array}{l}\text { Rate at } 300 \mathrm{~K} \\
\left(\mathrm{~mol} \mathrm{~s}^{-1} \mathrm{~g}-\mathrm{cat}^{-1}\right)\end{array}$ & $\begin{array}{l}\text { TOF at } 300 \mathrm{~K} \\
\left(\mathrm{~s}^{-1}\right)\end{array}$ & $\begin{array}{l}\text { Ea } \\
(\mathrm{kJ} / \mathrm{mol})\end{array}$ \\
\hline \multirow{3}{*}{ Pt } & DP & 1.0 & $1.3 \pm 0.3$ & 334 & $1.4 \times 10^{-7}$ & $2.7 \times 10^{-3}$ & 49 \\
\hline & IMP & 1.0 & $1.4 \pm 0.3$ & 339 & $1.9 \times 10^{-7}$ & $3.8 \times 10^{-3}$ & 60 \\
\hline & PD & 0.9 & $2.4 \pm 0.6$ & 363 & $2.4 \times 10^{-8}$ & $9.2 \times 10^{-3}$ & 53 \\
\hline \multirow{4}{*}{$\mathrm{Au}$} & DP & 0.7 & $3.1 \pm 0.7$ & 282 & $6.9 \times 10^{-7}$ & $3.4 \times 10^{-2}$ & 19 \\
\hline & DP & 1.8 & $2.7 \pm 0.6$ & 253 & $5.5 \times 10^{-6}$ & $1.2 \times 10^{-1}$ & 18 \\
\hline & IMP & 1.0 & $10<$ & 481 & $1.7 \times 10^{-10}$ & - & 58 \\
\hline & PD & 1.0 & $4.6 \pm 1.5$ & 477 & $1.5 \times 10^{-10}$ & $9.6 \times 10^{-6}$ & 56 \\
\hline
\end{tabular}

${ }^{*} T 1 / 2$ : temperature for $50 \%$ conversion of 1 vol\% Co in air under a space velocity of $2 \times 10^{-4} \mathrm{~h}^{-1}$. ml/g-cat. Preparation methods : DP deposition precipitation, IMP Impregnation, PD photochemical deposition.

a Au substrate, and observed appreciable catalytic activity (31). We have prepared a $\mathrm{Au} / \mathrm{TiO}_{2}$ catalyst by mechanically mixing a colloidal solution of $5 \mathrm{~nm}$ diameter Au particles with $\mathrm{TiO}_{2}$ powder, followed by calcination in air at different temperatures (32). Calcination at $873 \mathrm{~K}$ promotes the sintering of Au particles and the formation of larger particles with diameters above $10 \mathrm{~nm}$, but at the same time, with stronger contact (observed by TEM) leading to much higher catalytic activity than at 573K.

\section{2) Kind and Crystalline Type of Metal Oxide Support}

For CO oxidation, many oxides other than strongly acidic materials such as $\mathrm{Al}_{2} \mathrm{O}_{3}-\mathrm{SiO}_{2}$ and activated carbon can be used as a support and induce activity even below 300K. For Pd and Pt, semiconductor metal oxides lead to enhanced catalytic activities but at temperatures above 300K. Semiconductive metal oxides such as $\mathrm{TiO}_{2}, \mathrm{Fe}_{2} \mathrm{O}_{3}$, and $\mathrm{NiO}$ provide more stable $\mathrm{Au}$ catalysts than do insulating metal oxides such as $\mathrm{Al}_{2} \mathrm{O}_{3}$ and $\mathrm{SiO}_{2}$. Among Au supported on $\mathrm{Al}_{2} \mathrm{O}_{3}$, $\mathrm{SiO}_{2}$, or $\mathrm{TiO}_{2}$, the TOFs at room temperature under a moisture level of around 10 ppm are nearly equal, indicating that the contributions of the metal oxide supports are more or less similar in intensity (33). The difference appears in the moisture effect: $\mathrm{Al}_{2} \mathrm{O}_{3}$ and $\mathrm{SiO}_{2}$ require a concentration of $\mathrm{H}_{2} \mathrm{O}$ of at least 10 ppm higher than that for $\mathrm{TiO}_{2}$, for $\mathrm{CO}$ oxidation to proceed at room temperature (34). Alkaline earth metal hydroxides such as $\mathrm{Be}(\mathrm{OH})_{2}$ and $\mathrm{Mg}(\mathrm{OH})_{2}$ are excellent choices for demonstrating high activity at a temperature as low as $196 \mathrm{~K}(35,36)$. In contrast, when an acidic material such as $\mathrm{Al}_{2} \mathrm{O}_{3}-\mathrm{SiO}_{2}, \mathrm{WO}_{3}$, or activated carbon is used as a support, gold exhibits poor activity; even at temperatures above $473 \mathrm{~K}$ the conversions are far below $100 \%$ (33).

Low-temperature CO oxidation under an acidic environment has not yet been accomplished by any means. This reaction is very important in relation to polymer electrolyte fuel cells, which are operated at relatively low temperatures of around 373K (37). In order to use methanol directly as a fuel, the anode should also be active for the electrochemical oxidation of CO. However, the present Pt electrode is not only inactive but also deactivated. Lowtemperature CO oxidation under an acidic environment is a critical issue in opening a new stage of fuel cell development.

\section{3) Size of the Au Particles}

Figure 5 plots the TOFs of $\mathrm{CO}$ oxidation over $\mathrm{Pt} / \mathrm{SiO}_{2}$ and $\mathrm{Au} / \mathrm{TiO}_{2}$ as a function of the mean diameter of metal particles. A sharp increase in the TOF is observed with a decrease in the diameter from $4 \mathrm{~nm}$. In contrast, the Pt group of metals shows a decreasing or steady TOF (38). The rates over $\mathrm{Au} / \mathrm{TiO}_{2}$ were about one order of magnitude greater when measured as the temperature was lowered from $353 \mathrm{~K}$ than when measured as the temperature was raised from $203 \mathrm{~K}(4,39)$. This difference is assumed to occur from the accumulation of carbonate species on the surfaces of the support at low temperatures resulting in the loss of the

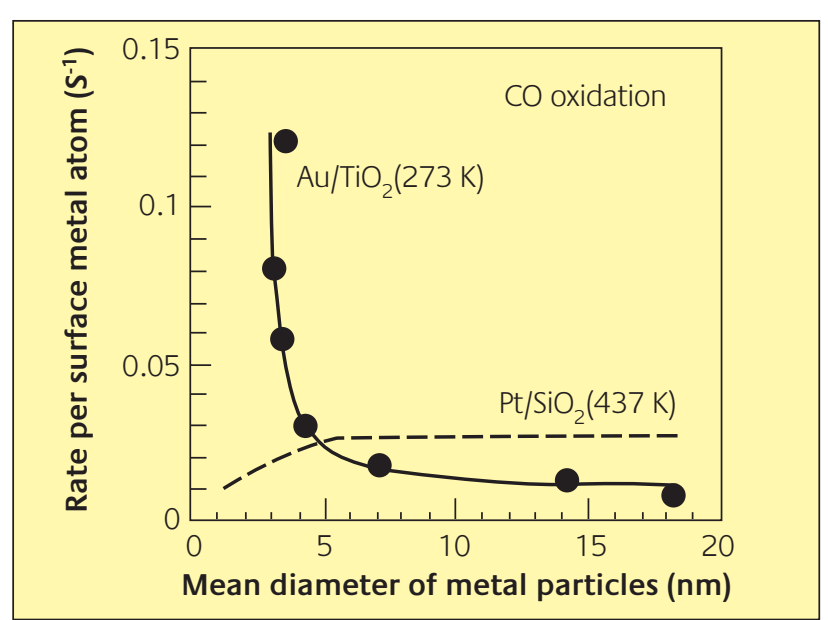

Figure 5

Turnover frequency (TOF) for CO oxidation over $\mathrm{Pt} / \mathrm{SiO}_{2}$ and $\mathrm{Au} / \mathrm{TiO} \mathrm{Z}_{2}$ 
activating power of the perimeter interfaces for $\mathrm{O}_{2}$. Therefore, the rate over $\mathrm{Au} / \mathrm{TiO}_{2}$, which was deactivated during experiments at lower temperatures, can be regarded as close to the rate of the $\mathrm{CO}$ reaction with $\mathrm{O}_{2}$ over the surfaces of the $\mathrm{Au}$ particles without the contribution of $\mathrm{O}_{2}$ activation at the perimeter interfaces. The one order of magnitude difference in the rate between fresh (obtained by high temperature measurements) and deactivated $\mathrm{Au} / \mathrm{TiO}_{2}$ can be ascribed to the contribution of the $\mathrm{TiO}_{2}$ support. Accordingly, the increase in the TOF can be explained if the adsorption sites for $\mathrm{CO}$ are edge, corner, or step sites, and the reaction zone is the periphery around the Au particles, the proportions of which increase in hemispherical Au particles with a decrease in their size (40).

\section{Kinetics and Reaction Mechanism of $\mathrm{CO}$ Oxidation}

Figure 6 shows Arrhenius plots for CO oxidation over noble metal catalysts. A unique feature of $\mathrm{Au}$ catalysts is that apparent activation energies (Ea) are very low. At temperatures below $300 \mathrm{~K}$, the value of Ea is 20 to $40 \mathrm{~kJ} / \mathrm{mol}$ and is nearly zero at temperatures above $300 \mathrm{~K}$. In contrast, Pt group metals have a value of Ea ranging from $50 \mathrm{~kJ} / \mathrm{mol}$ (Table 2) to $170 \mathrm{~kJ} / \mathrm{mol}$ (41) and are more active than Au but only at temperatures above 500K. At room temperature, Au is more active by 1-4 orders of magnitude.

The rate of $\mathrm{CO}$ oxidation over $\mathrm{Au} / \mathrm{TiO} 2, \mathrm{Au} / \mathrm{Fe}_{2} \mathrm{O}_{3}, \mathrm{Au} / \mathrm{CO}_{3} \mathrm{O}_{4}$ is independent of the concentration of $\mathrm{CO}$ and is slightly dependent on the concentration of $\mathrm{O}_{2}$ (on the order of 0 to 0.25) (42). Over unsupported Au powder with mean

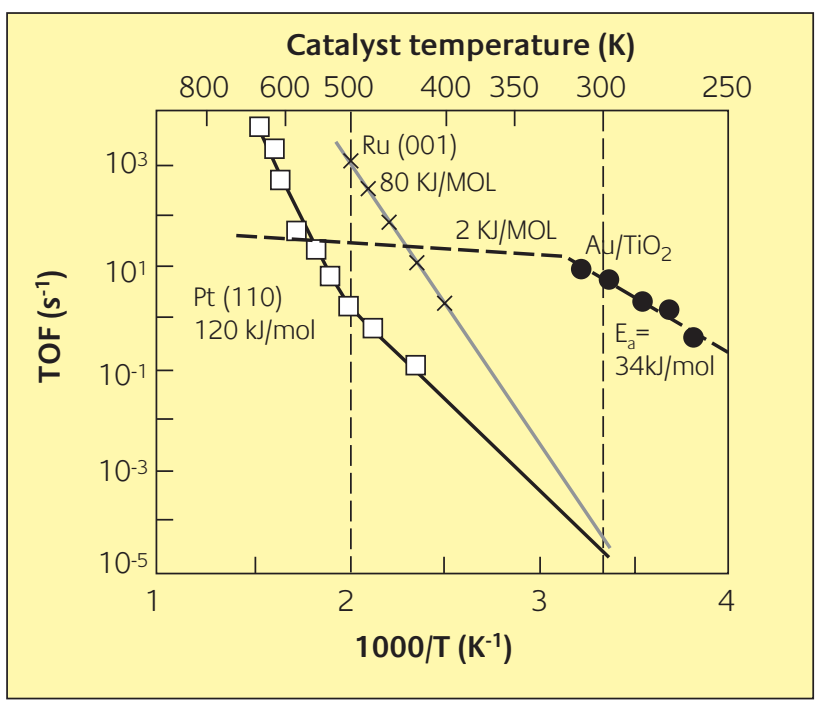

Figure 6

Arrhenius plots of the turn-over frequency (TOF) for CO oxidation over noble metal catalysts. The data for Pt group metals are taken from ref. [41]

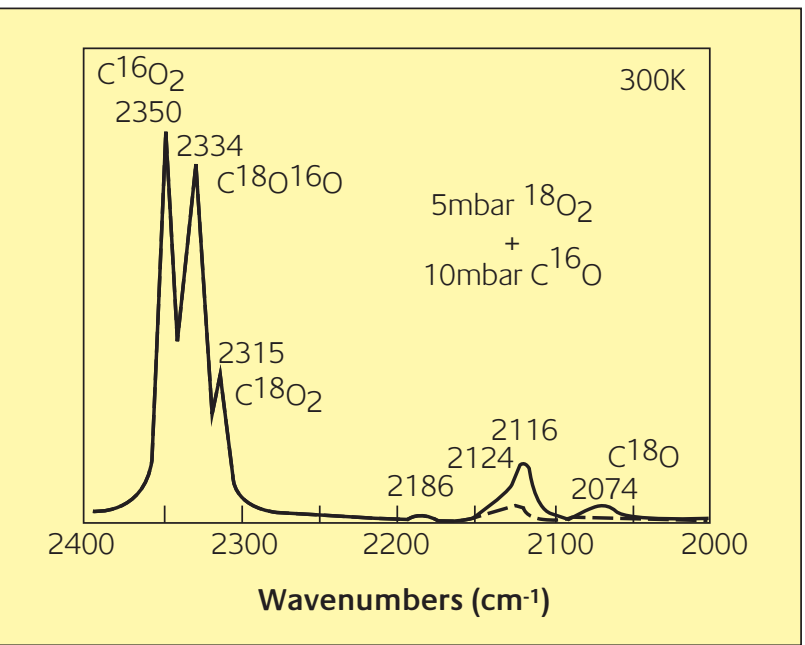

Figure 7

FT-IR spectra for the introduction of $\mathrm{C}^{16} \mathrm{O}$ at $300 \mathrm{~K}$ to $\mathrm{Au} / \mathrm{TiO} \mathrm{O}_{2}$ after preadsorption of ${ }^{18} \mathrm{O}_{2}$

diameters of $17 \mathrm{~nm}$, the rate is almost independent of the concentrations of $\mathrm{CO}$ and $\mathrm{O}_{2}$ (39). This independence suggests that $\mathrm{CO}$ and $\mathrm{O}_{2}$ are adsorbed on the catalyst surfaces nearly to saturation and that the reaction of the two adsorbed species is the rate-determining step.

In FT-IR spectra for $\mathrm{CO}$ adsorption at 90K over $\mathrm{Au} / \mathrm{TiO}_{2}$ calcined in air at different temperatures (43), the most active sample (calcined at 573K, with Au particles having a mean diameter of $2.4 \mathrm{~nm}$ ) exhibits the largest peak intensities, at 2110 to $2120 \mathrm{~cm}^{-1}$. This can be attributed to the linear adsorption of $\mathrm{CO}$ on the metallic Au sites (44). When the diameter of the Au particles becomes larger than $10 \mathrm{~nm}$ (sample calcined at 873K), the intensity of the peak is markedly reduced, indicating that $\mathrm{CO}$ adsorption might only occur on the steps, edges, and corners of the Au particles and not on the smooth surfaces. This agrees well with what has previously been discussed based on the self-consistent density functional theory calculations by Mavrikakis et al (40).

No direct experimental evidence has yet been presented showing that oxygen is activated for reacting with CO adsorbed on the Au surfaces or for whether oxygen molecule is dissociatively or non-dissociatively adsorbed. A TAP (temporal analysis of products) study of $\mathrm{O}_{2}$ adsorption and the reaction of $\mathrm{O}_{2}$ with $\mathrm{CO}(45,46),{ }^{18} \mathrm{O}_{2}$ isotope experiments $(43,45,46)$, and ESR measurements $(47,48)$ indicate that molecularly adsorbed $\mathrm{O}_{2}$, most likely $\mathrm{O}_{2}{ }^{-}$at the perimeter interface, is involved in the oxidation of $\mathrm{CO}$. Figure 7 shows FT-IR for the introduction of $\mathrm{C}^{16} \mathrm{O}$ at $300 \mathrm{~K}$ to $\mathrm{Au} / \mathrm{TiO}_{2}$ preadsorbed with ${ }^{18} \mathrm{O}_{2}(43)$. That $\mathrm{C}^{16} \mathrm{O}_{2}$ is formed in a quantity comparable to that of $\mathrm{C}^{16} \mathrm{O}^{18} \mathrm{O}$ means that the oxygen species $\left({ }^{16} \mathrm{O}\right)$ contained in the surface layer of the $\mathrm{TiO}_{2}$ support is also involved in $\mathrm{CO}$ oxidation at room temperature.

There are other arguments as well regarding the active species of $\mathrm{Au}$, especially in the case of $\mathrm{Au} / \mathrm{Fe}_{2} \mathrm{O}_{3}$. These include 


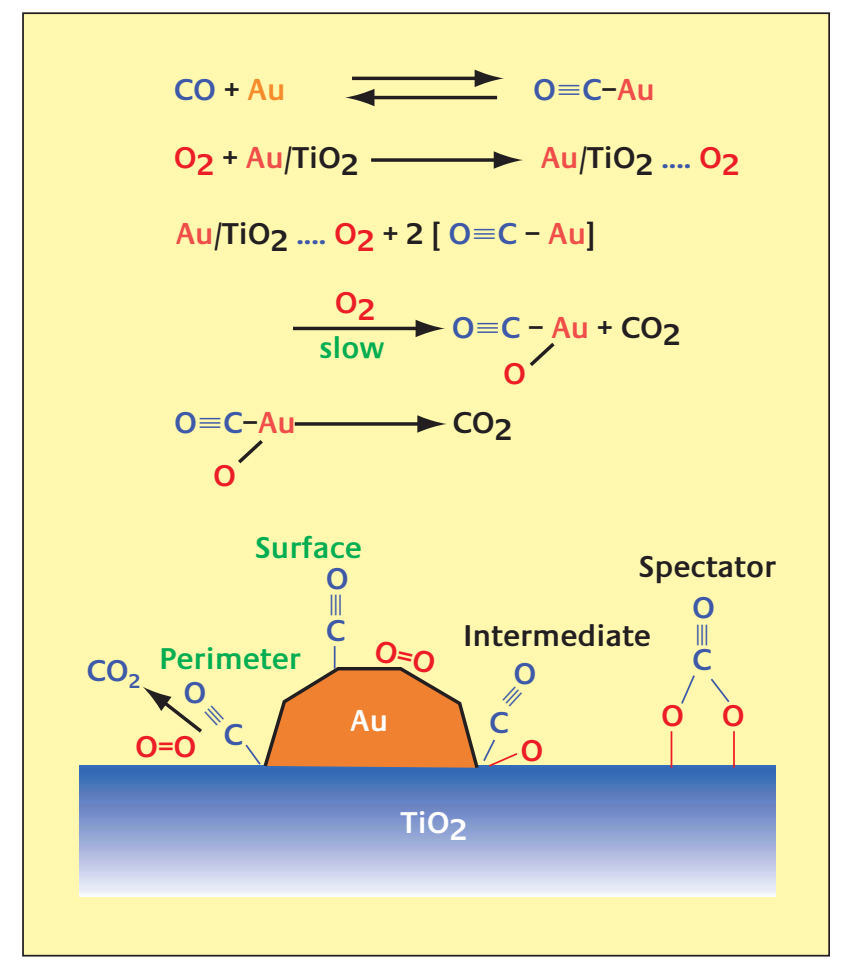

Figure 8

Probable pathways for CO oxidation over supported Au catalysts

oxidized Au species, $\mathrm{Au}^{+}$(49), $\mathrm{Au}^{\delta+}$ (50), or metal oxide support surfaces with modified reducibility by the interaction with $\mathrm{Au}$ nanoparticles $(51,52)$. It is unlikely that oxidic Au species are the major catalytically active phases because the most active supported Au catalysts are prepared by calcination in air at 573K, where Au precursors (hydroxides or organo complexes) are mostly transformed into metallic particles. A certain fraction of Au species remain as atomically dispersed species in the matrix of the support, as proved by EXAFS $(8,50,53,54)$, XPS (51), Mössbauer $(52,55)$, and IR of CO adsorbed $(43,49)$.
However, no correlation between the amount of oxidic Au species and catalytic activity has yet been presented. A reason why the samples primarily consisting of oxidic Au probably exhibited high catalytic activity might be that the oxidic Au species were transformed into metallic particles during reaction or storage of the sample after preparation.

Although metallic Au particles are indispensable, a question arises as to why the periphery of Au particles can activate $\mathrm{O}_{2}$ molecules at low temperatures. As firstly proposed by Bond and Thompson (56) and later discussed by Kung (57), it is probable that the perimeter interfaces contain oxidic Au species, most probably $\mathrm{Au}(\mathrm{OH})_{3}$ or $\mathrm{Au}(\mathrm{OH})$, under usual conditions wherever $\mathrm{H}_{2} \mathrm{O}$ is present at concentrations above 1 ppm. These hydroxides might be stabilized and reversibly formed and decomposed by the aid of the metal oxide supports.

An argument proposed by Goodman and his coworkers is that the non-metallic nature of Au clusters leads to high catalytic activity $(23,58)$. This conclusion is questionable as far as CO oxidation is concerned. The transition of the electronic state was measured for one specific Au cluster of a defined diameter by scanning tunneling spectroscopy, whereas the catalytic activity was measured for an entire $\mathrm{Au} / \mathrm{TiO}_{2}$ model catalyst specimen with a mean diameter of all Au clusters. A maximum in the catalytic activity with respect to the mean diameter of the Au clusters was observed where the transition of the electronic state of the specific Au cluster occurred from metallic to non-metallic. This result can be more reasonably explained by assuming that metallic Au surfaces are necessary for $\mathrm{CO}$ adsorption and that the peripheries act as reaction zones with $\mathrm{O}_{2}$. A maximum total surface area or number of step sites (40) of metallic Au clusters is obtained at a thickness of 2 atoms, where the transition to non-metallic state begins.

\section{Table 3}

Ongoing and potential applications of Au catalysts

\begin{tabular}{|c|c|c|}
\hline Fields of applications & Reactants or Reactions & Support materials \\
\hline Indoor air quality control & $\begin{array}{l}\text { odour (commercialized), CO } \\
\text { sick house gases }\end{array}$ & $\begin{array}{l}\mathrm{Fe}_{2} \mathrm{O}_{3} \\
\mathrm{TiO}_{2}\end{array}$ \\
\hline Pollutant abatement & $\begin{array}{l}\text { dioxin oxidation-decomposition } \\
\mathrm{NO} \text { reduction } \\
\mathrm{N}_{2} \mathrm{O} \text { decomposition }\end{array}$ & $\begin{array}{l}\mathrm{Fe}_{2} \mathrm{O}_{3} \\
\mathrm{Al}_{2} \mathrm{O}_{3} \\
\mathrm{CO}_{3} \mathrm{O}_{4}\end{array}$ \\
\hline $\mathrm{H}_{2}$ energy carrier & $\begin{array}{l}\text { water-gas shift } \\
\text { co removal } \\
\text { fuel cell anode }\end{array}$ & $\begin{array}{l}\mathrm{ZrO}_{2}, \mathrm{CeO}_{2} \\
\mathrm{Al}_{2} \mathrm{O}_{3}, \mathrm{Mn}_{2} \mathrm{O}_{3}, \mathrm{Fe}_{2} \mathrm{O}_{3} \\
\text { carbon black }\end{array}$ \\
\hline Chemical process & $\begin{array}{l}\text { hydrochlorination } \\
\text { hydrogenation } \\
{[\mathrm{C}=\mathrm{C}, \mathrm{C}=\mathrm{O} \neq \mathrm{C}=\mathrm{C}, \mathrm{C}-\mathrm{OH}]} \\
\text { liquid-phase selective oxidation } \\
\text { propylene epoxidation }\end{array}$ & $\begin{array}{l}\mathrm{AuCl}_{3} / \text { activated carbon } \\
\mathrm{ZnO} \\
\text { activated carbon } \\
\mathrm{TiO}_{2} \text { (anatase) and } \mathrm{Ti}_{-} \mathrm{SiO}_{2}\end{array}$ \\
\hline
\end{tabular}


Based on the above arguments and by taking into account a recent overview (59), the most probable pathway for CO oxidation over supported Au catalysts can be depicted as shown in Figure 8.

\section{Applications and Future Prospect of Gold Catalysts}

Gold catalysts with selected support materials can also promote many reactions other than CO oxidation. Table 3 lists such reactions, which usually take place at much lower temperatures or with much higher degrees of selectivity over Au catalysts than over other metal catalysts (5).

The characteristic features of supported gold catalysts are remarkable structure sensitivity of their catalytic performance, low apparent activation energies (active at low temperatures), and moisture activation. By taking advantages of these properties, $R \& D$ efforts on Au catalysts are expected to expand in three directions. The first direction involves the discovery of new capabilities for Au particles larger than $2 \mathrm{~nm}$ that are stable up to 673K. Combinations with other metal catalysts might contribute to further develop the capabilities of $\mathrm{Au}$ catalysts. Although $\mathrm{Ir} / \mathrm{La}_{2} \mathrm{O}_{3}$ itself is weakly active, it can effectively enhance the catalytic activity of $\mathrm{Pd} / \mathrm{SnO}_{2}$ and $\mathrm{Au} / \alpha-\mathrm{Fe}_{2} \mathrm{O}_{3}$. The booster effect of Ir catalysts yielded a 95\% decomposition of dioxin from the outlet gases of incinerators even at $423 \mathrm{~K}$ at an hourly space velocity of $12,000 \mathrm{~h}^{-1} \cdot \mathrm{ml} / \mathrm{g}$-cat. (28).

The second direction involves application of the mechanism of Au catalysis and the techniques developed for preparing Au catalysts to other noble metals. In most cases, the genesis of the catalysis of Au is ascribed to the perimeter interfaces around the Au particles. This presents us with a new guiding principle for creating a wide range of new catalytic systems, because the combination of catalytic metals with a variety of support materials should present numerous novel catalysts. Some good examples are $\mathrm{Pd} / \mathrm{CeO}_{2}$ and $\mathrm{Pt} / \mathrm{ZrO}_{2}$ prepared by coprecipitation or depositionprecipitation for the low-temperature decomposition and synthesis of methanol $(60,61)$ and for the low-temperature oxidation of $\mathrm{CO}$ and reduction of $\mathrm{NO}$ (62).

The third direction involves the development of cluster science for Au particles smaller than $2 \mathrm{~nm}$. Fundamental work has recently led to an understanding of the unique catalysis of Au as well as its size- and structure-dependency. Through the use of surface science techniques using welldefined catalytic materials, generally size-selected Au clusters deposited on single crystalline metal oxides such as MgO (63) and $\mathrm{TiO}_{2}(23,58,64,65)$, an atomic scale perspective is being developed in combination with theoretical calculations $(40,66,67)$. It is also instructive that the catalytic activity changes dramatically depending on the three-dimensional structure of the 13-atom Au clusters (36). Recently, it has been reported that a 55 atom cluster is specifically inert even against active atomic oxygen species (68). Wang and his coworkers have reported that a 20 atom cluster of tetrahedron structure has a large energy gap between $\mathrm{HOMO}$ and LUMO and is more stable than fullerene (69). From this perspective, Au might be the best research target because Au itself is poorly active and detectable catalytic activity and marked change in reactivity is only obtained when the Au particles have a specific structure and size. What is also an advantage in studying Au model catalysts is that the activity can often be observed at lower temperatures where designed structures can be maintained.

To increase the effectiveness of recent attempts to combine experimental work using real and model catalysts with theoretical calculations (70), the effect of moisture should also be considered. Most work in surface science occurs in an ultra high vacuum, while measurements of the activity of real catalysts are conducted in a fixed bed flow reactor using reactant gas containing a moisture level of at least $1 \mathrm{ppm}$, usually $10 \mathrm{ppm}$. The catalyst surfaces are covered with $\mathrm{OH}$ groups and water molecules at room temperature. For $\mathrm{CO}$ oxidation, which does not produce $\mathrm{H}_{2} \mathrm{O}$ and proceeds at temperatures below 373K, moisture markedly changes the catalytic activity of the metal oxides and the $\mathrm{Au}$ catalysts. Under dry conditions with an $\mathrm{H}_{2} \mathrm{O}$ concentration of $80 \mathrm{ppb}, \mathrm{CO}$ oxidation can occur over $\mathrm{CO}_{3} \mathrm{O}_{4}$ without $\mathrm{Au}$ even at $210 \mathrm{~K}$ (71,72), while supported $\mathrm{Au}$ catalysts prefer moisture $(34,73)$.

\section{Conclusions}

1) There are at least eight techniques for preparing highly dispersed gold catalysts. The catalytic performances of gold catalysts markedly depend on the preparation methods and conditions because the following three factors define the genesis of unique catalysis by gold: strong contact between Au particles and the support, selection of the support, and the size of the Au particles.

2) Perimeter interfaces provide the sites for reaction, while metallic Au surfaces are still required as reservoirs for a reactant.

3) Very low apparent activation energies and enhancement by moisture contribute to the advantages of using $\mathrm{Au}$ catalysts in environmental applications, where lowtemperature operation is often preferred.

4) Gold is the best example for fundamental studies on the effect of size below $2 \mathrm{~nm}$ through model catalysts and theoretical calculations.

5) The methods of preparation and the mechanisms that 
induce the high catalytic activity of Au are applicable to other metals.

\section{About the Author}

Masatake Haruta has been Director of the Research Institute for Green Technology at the National Institute of Advanced Industrial Science and Technology, Japan, since April 2001. He received his doctor's degree from Kyoto University in 1976.

\section{References}

1 M. Haruta, N. Yamada, T. Kobayahsi and S. lijima, J. Catal., 1989, 115, 301

2 G.C. Bond and D.T. Thompson, Catal. Rev. - Sci. Eng., 1999, 41, 319

3 M. Haruta and M. Daté, Appl. Catal. A: General, 2001, 222, 427

4 M. Haruta, CATTECH, 2002, 6 (3), 102

5 M. Haruta, Chem. Record, 2003, 3, 75

6 M. Haruta, S. Tsubota and M. Okumura, "Advances in Catalyst Preparation (in Japanese)", Y. Ono et al. eds., Assoc. for the Promotion of Catal. Preparation Chem., Tokyo, 2000, p39

7 M. Haruta, H. Kageyama, N. Kamijo, T. Kobayashi and F. Delannay, Stud. Surf. Sci. Catal., 1988, 44, 33

8 H. Kageyama, N. Kamijo, T. Kobayashi and M. Haruta, Physica, 1989, B158, 183

9 M. Haruta, T. Kobayashi, S. Tsubota and Y. Nakahara, Jpn. Pat. 1778730 (1993)

10 R.M. Torres Sanchez, A. Ueda, K. Tanaka and M. Haruta, J. Catal., 1997, 168, 125

11 M. Shibata, N. Kuwata, T. Matsumoto and H. Kimura, Chem. Lett., 1985, 1605

12 T. Kobayashi, M. Haruta, S. Tsubota and H. Sano, Sensors and Actuators B1, 1990, 222

13 S. Tsubota, M. Haruta, T. Kobayashi, A. Ueda and Y. Nakahara, Stud. Surf. Sci. Catal., 1991, 63, 695

14 W. Vogel, D.A.H. Cunningham, K. Tanaka and M. Haruta, Catal. Lett., 1996, 40, 175

15 Y. Yuan, A.P. Kozlova, K. Asakura, H. Wan, K. Tsai and Y. Iwasawa, J. Catal., 1997, 170, 191

16 M. Okumura and M. Haruta, Chem. Lett., 2000, 396.

17 M. Okumura, K. Tanaka A. Ueda and M. Haruta, Solid State Ionics, 1997, 95, 143

18 M. Okumura, S. Tsubota, M. Iwamoto and M. Haruta, Chem. Lett., 1998, 315

19 J-D. Grunwaldt, C. Kiener, C. Wögerbauer and A. Baiker, J. Catal., 1999, 181,223

20 L. Prati and M. Rossi, "Green Chemistry: Challenging Perspectives", P. Tundo, P. Anastas, eds., Oxford, 2000, p183

21 W.T. Wallace and R.L. Whetten, J. Phys.Chem., 2000, B104, 10964

22 Kishi, M. Daté and M. Haruta, Surf. Sci., 2001, 486, L475
23 M. Valden, S. Pak, X. Lai and D.W. Goodman, Catal. Lett., 1998, 56, 7

24 R. Zanella, S. Giorgio, C.R. Henry and C. Louis, J. Phys. Chem. B., 2002, 106, 7634

25 C.E. Larsson, T.H. Baum and R.L. Jackson, J Electrochem. Soc., 1987, 134, 266

26 T. Akita, P. Lu, S. Ichikawa, K. Tanaka and M. Haruta, Surf. Interface Anal., 2001, 31, 73

27 M. Haruta, B.S. Uphade, S. Tsubota and A. Miyamoto, Res. Chem. Intermed.,1998, 24, 329

28 M. Okumura, T. Akita, M. Haruta, X. Wang, O. Kajikawa and O. Okada, Appl. Catal. B: Environomental, 2003, 41, 43

29 G. Ertl, Chem. Record, 2001, 1, 33

30 G.R. Bamwenda, S. Tsubota, T. Nakamura and M. Haruta, Catal. Lett., 1997, 44, 83

31 Z.M. Liu and M.A. Vannice, Catal. Lett., 1997, 43, 51

32 S. Tsubota, T. Nakamura, K. Tanaka and M. Haruta, Catal. Lett., 1998, 56, 131

33 M. Okumura, S. Nakamura, S. Tsubota, T. Nakamura and M. Azuma, M. Haruta, Catal. Lett., 1998, 51, 53

34 M. Daté and M. Haruta, J. Catal., 2001, 201, 221

35 M. Haruta, T. Kobayashi, S. Tsubota and Y. Nakahara, Chem. Express, 1998, 3, 159

36 D.A.H. Cunningham, W. Vogel, H. Kageyama, S. Tsubota and M. Haruta, J. Catal., 1998, 177, 1

37 J. Lipkowski and P.N. Jr. Ross, "Electrocatalysis, Frontiers in Electrochemistry”, VCH, New York, 1997, Vol. 5

38 M. Haruta, "Catalysis and Electrocatalysis on Nanoparticles", A. Wieckowski, E.R. Savinova, C.G. Vayenas, eds., Marcel Dekker, New York, 2003, p645

39 Y. lizuka, T. Tode, T. Takao, K. Yatsu, T. Takeuchi, S. Tsubota and M. Haruta, J. Catal., 1999, 187, 50

40 M. Mavrikakis and P. Stoltze and J.K. Nørskov, Catal. Lett., 2000, 64, 101

41 C.H.F. Peden, "Surface Science of Catalysis - In Situ Probes and Reaction Kinetics", ACS Symp. Ser. 482, D.J. Dwyer and F.M. Hoffmann, eds., Amer. Chem. Soc., Washington DC, 1992, p. 143

42 M. Haruta, S. Tsubota, T. Kobayashi, H. Kageyama and M.J. Genet and B. Delmon, J. Catal., 1993, 144, 175

43 F. Boccuzzi, A. Chiorino, M. Manzoli, P. Lu, T. Akita and S. Ichikawa and M. Haruta, J. Catal., 2001, 202, 256

44 C. Ruggiero and P. Hollins, Surf. Sci., 1997, 377-379, 583

45 M. Olea, M. Kunitake, T. Shido and Y. Iwasawa, Phys. Chem. Chem. Phys., 2001, 3, 627

46 M.M. Schubert, S. Hackenberg, A.C. van Veen, M. Muhler, V. Plzak and R.J. Behm, J. Catal., 2001, 197, 113

47 H. Liu, A.I. Kozlov, A.P. Kozlova, T. Shido, K. Asakura and Y. Iwasawa, J. Catal., 1999, 185, 252

48 M. Okumura, J.M. Coronado, J. Soria, M. Haruta and J.C. Conesa, J. Catal., 2001, 203, 168

49 S. Minicò, S. Scirè, C. Crisafulli, A.M. Visco and S. Galvagno, Catal. Lett., 1997, 47, 273

50 Z. Hao, L. An, H. Wang and T. Hu, React. Kinet. Catal. Lett., 2000, 70, 153. 
51 D. Horváth, L. Toth and L. Guczi, Catal. Lett., 2000, 67, 117

52 F.E. Wagner, S. Galvagno, C. Milone, A.M. Visco, L. Stievano and S. Calogero, J. Chem. Soc. Faraday Trans., 1997, 93, 3403

53 H. Kageyama, K. Kadono, K. Fukumi, T. Akai, N. Kamijo and M. Haruta, J. Phys. IV France 7, 1997, C2, 935

54 S. Tsubota, D.A.H. Cunningham and M. Haruta, Stud. Surf. Sci. Catal., 1995, 91, 227

55 Y. Kobayashi, S. Nasu, S. Tsubota and M. Haruta, Hyperfine Interactions, 2000, 126, 95

56 G.C. Bond and D.T. Thompson, Gold Bull., 2000, 33, 41

57 H.H. Kung, M.C. Kung and C.K. Costello, J. Catal., 2003, 216, 425

58 M. Valden, X. Lai and D.W. Goodman, Science, 1998, 281, 1647

59 A. Cho, Science, 2003, 299, 1684

60 Y. Usami, K. Kagawa, M. Kawazoe, Y. Matsumura, H. Sakurai and M. Haruta, Appl. Catal. A: General, 1998, 171, 123

61 W. Shen, Y. Ichihashi, M. Okumura and Y. Matsumura, Catal. Lett., 2000, 64,23
62 S. Golunsky, R. Rajaram, N. Hodge, G. Hutchings and C.J. Kiely, Catal. Today, 2002, 72, 107

63 U. Heiz and W.-D. Schneider, J. Phys. D: Appl. Phys., 2000, 33, R85

64 F. Cosandey and T.E. Madey, Surf. Rev. Lett., 2001, 8, 73

65 V.A. Bondzie, S.C. Parker and C.T. Campbell, Catal. Lett., 1999, 63, 143

66 B. Hammer and J.K. Nørskov, Nature, 1995, 376, 238

67 S. Abbet, U. Heiz, H. Häkkinen and U. Landman, Phys. Rev. Lett., 2001, 86, 5950

68 H.-G. Boyen, et al., Science, 2002, 297, 1533

69 J. Li, X. Li, H.-J. Zhai, L. -S. Wang, Science, 2003, 299, 864

70 R. Schlögl, CATTECH, 2001, 5, 146

71 D.A.H. Cunningham, T. Kobayashi, N. Kamijo and M. Haruta, Catal. Lett., 1994, 25, 257

72 M. Haruta, M. Yoshizaki, D.A.H. Cunningham and T. Iwasaki, “Ultraclean Technology (in Japanese)", 1996, 8, 1

73 M. Daté, M. Okumura, S. Tsubota and M. Haruta, submitted to Proc. Gold 2003, Vancouver, 2003 